\title{
Serum enzyme changes after intramuscular bleeding in patients with haemophilia and Christmas disease
}

\author{
CHARLES D. FORBES, ${ }^{1}$ JOHN KING, COLIN R. M. PRENTICE, AND \\ GEORGE P. MCNICOL ${ }^{2}$
}

From the Departments of Medicine and Biochemistry, Royal Infirmary, Glasgow, Scotland

SYNOPSIS Serum creatine kinase, lactate dehydrogenase, aspartate and alanine transaminases, and aldolase were determined in 41 hospital inpatients with haemophilia or Christmas disease and no significant differences from the normal ranges were found. ${ }^{3}$ Levels of these enzymes in a further 10 such patients who had sustained muscle haematomata were determined: in all of these there was a consistent rise in the level of creatine kinase, the peak occurring between 36 and 96 hours.

In bleeding disorders a rise in serum creatine kinase levels may be useful as a diagnostic test for intramuscular haemorrhage.

Elevation of serum creatine kinase (CK) is known to be the most sensitive enzyme test of skeletal and cardiac muscle damage and has been widely used in diagnosis (Ebashi, Toyokura, Momoi, and Sugita, 1959; Dreyfus, Schapira, Scebat, Renais, and Lenègre, 1960; Okinaka, Kumagai, Ebashi, Sugita, Momoi, Toyokura, and Fujie, 1961; Wright, Clarkson, Brown, and Fuster, 1971). Transient rises in levels of CK have also been reported after strenuous muscular exercise (Graig and Ross, 1963; Schneider and Heise, 1963), after epileptic seizures (Wilson, 1971, personal communication), and after extensive injuries in road or industrial accidents (King, 1970). Similarly, elevation of lactate dehydrogenase (LD) and aldolase (ALS) has been reported after prolonged muscular exercise (Baumann, Escher, and Richterich, 1962; Remmers and Kaljot, 1963).

We report here the changes in serum levels of creatine kinase, lactate dehydrogenase, aldolase, and aspartate and alanine transaminases (AST, ALT) in patients with haemophilia and Christmas disease who had suffered haemorrhage into muscles either spontaneously or as a result of trauma.

Received for publication 10 October 1972.

${ }^{1}$ Reprint requests: Dr C. D. Forbes, Department of Medicine, Royal Infirmary, 86 Castle Street, Glasgow, C4

${ }^{2}$ NEW ADDRESS: Department of Medicine, University of Leeds, Leeds General Infirmary, Leeds

${ }^{3}$ Nomenclature of enzymes

Creatine kinase

Lactate dehydrogenase

Aspartate transaminase

Alanine transaminase

Aldolase

CK

LD

AST

ALT

ALS

\section{Methods and Materials}

All enzymes were assayed by initial reaction rate $\overrightarrow{0}$ procedures at $37^{\circ} \mathrm{C}$. The transaminases and lactate $N$ dehydrogenase assays were carried out on the LKB 8600 reaction rate analyser using Boehringe $\vec{r}^{+}$ test combination reagents. Boehringer kits were also employed for estimating aldolase and creatine kinase activities initially on a Unicam SP800 and latterly on a Unicam SP1800 recording spectrophotometer with temperature control by a circulating Heto water bath. Enzyme activities are expressed in International Units at $37^{\circ} \mathrm{C}$. (International Union of Biochemistry, 1961, 1965).

Normal ranges of activities were established in a hospital patient population by truncated probit analysis (Neumann, 1968) as follows: AST 9-34 IU/litre, ALT 5-26 IU/litre, LD 115-465 IU/litre, ALS 0-6 IU/litre, and CK 0-100 IU/litre at a reaction temperature of $37^{\circ} \mathrm{C}$ (McQueen, Garland, and Morgan, 1972).

Electrophoretic separation of lactate dehydrogenase isoenzymes was performed as previously described (Forbes, King, and McNicol, 1971).

Assays of antihaemophilic factor (AHF) or Christmas factor (CF) were performed by the method as described by Breckenridge and Ratnoff

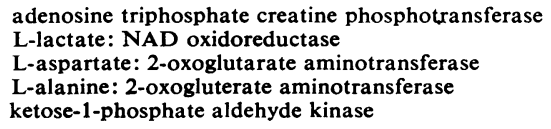

2.7.3.1

1.1.1.27

2.6.1.1

2.6.1.2

4.1.2.7 
(1962) and clinical grading of the severity of the defect was as described by Biggs and Macfarlane (1962).

Estimation of the serum levels of enzymes was undertaken in a series of 41 control patients with haemophilia or Christmas disease. They were all inpatients in hospital and had been rested in bed for at least 24 hours. All had some clinical bleeding problem, eg, haematuria, haemoptysis, haemarthrosis, haematemesis and melaena, or epistaxis. None had clinical evidence of muscle bleeding.

Ten patients with haemophilia or Christmas disease with obvious or suspected muscle haematomata were investigated; clinical details are shown in Table I. Serial blood samples were taken from the time of admission until the enzyme levels had returned to baseline values.

\section{Results}

NORMAL LEVELS OF SERUM ENZYMES IN HAEMOPHILIAC PATIENTS WITHOUT MUSCLE HAEMATOMATA

The results are shown in Table II. There are no significant differences in CK, LD, AST, or ALT levels in the haemophilic population from the normal values found in the hospital population.
ENZYME LEVELS IN HAEMOPHILIAC PATIENTS WITH MUSCLE HAEMATOMAS

The results are shown in Table III. There were significant rises in creatine kinase in all 10 patients with muscle haematomas. The time taken to reach peak CK activities varied from 36 hours to 96 hours with a mean of 56 hours after the onset of haematoma.

In three of the patients with clinically very small muscle haematomas, the peak level of CK was relatively low and only slightly above the upper limit of the normal range but all these patients had started with low levels of CK activity and showed the same rise after injury as the others. Lactate dehydrogenase was raised above the normal range in only three patients despite serial estimations. Electrophoresis consistently showed the pattern $1>2>3>5>4$. One of these patients (patient 2) had evidence of duplication of $L D_{1}$. One patient had a transient elevation of AST and two had transient elevation of ALT (patients 1 and 9). Aldolase was slightly elevated in one patient only.

\section{Discussion}

In this study the only enzyme in which a consistent rise was found after muscle haematoma formation

\begin{tabular}{|c|c|c|c|c|c|c|}
\hline $\begin{array}{l}\text { Patient } \\
\text { Number }\end{array}$ & $\begin{array}{l}\text { Age } \\
\text { (yr) }\end{array}$ & $\begin{array}{l}\text { Grade of } \\
\text { Defect }\end{array}$ & $\begin{array}{l}\text { AHF or CF } \\
\text { Level (units } \\
\text { per } 100 \mathrm{ml})\end{array}$ & $\begin{array}{l}\text { Site of } \\
\text { Haematoma }\end{array}$ & Clinical Size & Cause \\
\hline $\begin{array}{r}1 \\
2 \\
3 \\
4 \\
5 \\
6 \\
7 \\
8 \\
9 \\
10\end{array}$ & $\begin{array}{l}15 \\
15 \\
15 \\
46 \\
21 \\
42 \\
34 \\
24 \\
13 \\
20\end{array}$ & $\begin{array}{l}\text { Severe } \\
\text { Severe } \\
\text { Severe } \\
\text { Moderate } \\
\text { Severe } \\
\text { Severe } \\
\text { Severe } \\
\text { Severe } \\
\text { Severe } \\
\text { Severe }^{1}\end{array}$ & $\begin{array}{l}0 \\
0 \\
0 \\
3 \\
0 \\
0 \\
0 \\
0 \\
0 \\
0\end{array}$ & $\begin{array}{l}\text { Bilateral, thigh } \\
\text { Thigh } \\
\text { Thigh } \\
\text { Buttock } \\
\text { Buttock } \\
\text { Thigh² } \\
\text { Thigh } \\
\text { Deltoid² } \\
\text { Buttock } \\
\text { Diagnostic problem }\end{array}$ & $\begin{array}{l}\text { Massive } \\
\text { Massive } \\
\text { Massive } \\
\text { Moderate } \\
\text { Moderate } \\
\text { Small } \\
\text { Small } \\
\text { Small } \\
\text { Small } \\
\end{array}$ & $\begin{array}{l}\text { Automobile accident } \\
\text { Intramuscular injection } \\
\text { Traumatic } \\
\text { Traumatic } \\
\text { Traumatic } \\
\text { Traumatic } \\
\text { Spontaneous } \\
\text { Spontaneous } \\
\text { Intramuscular injection }\end{array}$ \\
\hline
\end{tabular}

Table I Clinical details of the 10 patients with haemophilia or Christmas disease with intramuscular haematoma from various causes

'Patient had Christmas disease.

${ }^{2}$ Associated with acute haemarthrosis of joint.

\begin{tabular}{|c|c|c|c|c|}
\hline & $\begin{array}{l}\text { Creatine } \\
\text { Kinase }\end{array}$ & $\begin{array}{l}\text { Lactate } \\
\text { Dehydrogenase }\end{array}$ & $\begin{array}{l}\text { Aspartate } \\
\text { Transaminase }\end{array}$ & $\begin{array}{l}\text { Alanine } \\
\text { Transaminase }\end{array}$ \\
\hline $\begin{array}{r}\text { Control haemophiliac group (mean) } \\
\text { (range) }\end{array}$ & $\begin{array}{l}32 \cdot 7 \\
0-75\end{array}$ & $\begin{array}{c}271 \\
165-465\end{array}$ & $\begin{array}{r}18 \cdot 6 \\
10-35\end{array}$ & $6-35$ \\
\hline Normal values for hospital population & $0-100$ & $115-465$ & $9-35$ & $5-26$ \\
\hline
\end{tabular}

Table II Normal levels of creatine kinase, lactate hydrogenase, aspartate and alanine transferases in a control group of inpatients with haemophilia and Christmas disease

No patient had clinical evidence of muscle bleeding. There is no significant difference between these groups. 


\begin{tabular}{|c|c|c|c|c|c|}
\hline \multirow[t]{2}{*}{ Patient Number } & \multicolumn{5}{|c|}{ Peak Level of Enzyme (IU/litre) } \\
\hline & Creatine Kinase & Lactate Dehydrogenase & Aspartate Transaminase & Alanine Transaminase & Aldolase \\
\hline 1 & 17400 & 2100 & 348 & 88 & - \\
\hline 2 & 575 & $1020^{1}$ & 26 & 15 & $4 \cdot 0$ \\
\hline 3 & 330 & $474^{1}$ & 27 & 11 & $9 \cdot 4$ \\
\hline 4 & 568 & $420^{1}$ & 12 & 10 & - \\
\hline 5 & 196 & $380^{1}$ & 18 & 11 & - \\
\hline 6 & 167 & $410^{1}$ & 14 & 12 & - \\
\hline 7 & 112 & $335^{1}$ & 15 & 11 & - \\
\hline 8 & 102 & 250 & 13 & 13 & $4 \cdot 85$ \\
\hline 9 & 125 & 415 & 23 & 39 & 一 \\
\hline 10 & 177 & $320^{1}$ & 11 & 10 & - \\
\hline
\end{tabular}

Table III Peak levels of enzymes in nine patients with intramuscular bleeding and one patient with suspected bleeding into the sacro-spinalis muscle

${ }^{1}$ Electrophoresis of LD $1>2>3>5>4$.

is creatine kinase. The 'normal' activity of CK in serum is probably derived from muscle and in a healthy population the levels are influenced by the degree of muscular activity (Griffiths, 1966).

Within 24 hours of the occurrence of muscle bleeding, there is a rise in level of creatine kinase which may persist for a further 48 hours before falling to normal values by the fourth day after injury. The extent of haematoma formation in muscle is difficult to assess clinically but there would appear to be a crude positive correlation between the size of haematoma and the peak level of CK activity. Lactate dehydrogenase, AST, ALT, and ALS showed no consistent rise after muscle bleeding.

Determination of the isoenzymes of LD by electrophoresis was generally unhelpful. One patient (patient 1) had duplication of $\mathrm{LD}_{1}$ which was probably due to the large amount of plasma concentrate (cryoglobulin precipitate) infused during and immediately after surgery to repair a ruptured ureter (Forbes et al, 1971). The other five patients in whom isoenzymes were estimated showed a pattern $1>2>3>5>4$. This probably represents release of LD from red cells in the haematoma; however, the pattern $5>4$ may possibly represent leakage of muscle lactate dehydrogenase.

The cause of the rise in CK levels after exercise and in disease states of muscle is not known. It has been suggested that it is due to leakage of the enzyme through the sarcolemma and it has been further suggested (Aebi, Richterich, Colombo, and Rossi, 1961) that CK is more likely to pass to the extracellular compartment than the other muscle enzymes, because of its high concentration and low molecular weight (Schmidt and Schmidt, 1967).

The majority of patients in this series had muscle haematomas which were clinically obvious and presented no diagnostic problems. Estimation of CK, however, shows such a consistent elevation following muscle bleeding that it may be of value in the haemophiliac who presents with abdominal pain of obscure aetiology. Case 10 illustrates the potential usefulness of $\mathrm{CK}$ estimation as a diagnostic test. This patient presented with severe loin pain which was initially diagnosed as being due to pyelonephritis. However the urine was sterile and both an isotope renogram and an intravenous pyelogram were normal. After infusion of plasma, pain stopped and the patient was sent home. Similar symptoms recurred two weeks later and a pattern of enzyme change similar to that seen io association with muscle haematoma formation was found. The diagnosis would seem to have beem. bleeding into the sacrospinalis muscle.

It is suggested that estimation of creatine kinase may be of value in the diagnosis of occult muscle haemorrhage in patients with bleeding disorders and it is possible that it may be of value in the differentiation of acute appendicitis from haemorrhage into the ileo-psoas muscle, a recurrent clinical problem in haemophilia.

\section{References}

Aebi, U., Richterich, R., Colombo, J. P., and Rossi, E. (1961). Progressive muscular dystrophy II. Biochemical identification of the carrier state in the recessive sex-linked juvenile (Duchenne) type by serum creatine-phosphokinase determinations. Enzymol. biol. clin. (Basel), 1, 61-74.

Baumann, P., Escher, J., and Richterich, R. (1962). Das Verhalten von Serum-Enzymen bei sportlichen Leistungen. Schweiz. Z. Sportmed., 10, 33-51.

Biggs, R., and Macfarlane, R. G. (1962), Human Blood Coagulation and its Disorders, 3rd ed. Blackwell, Oxford.

Breckenridge, R. T., and Ratnoff, O. D. (1962). Studies on the nature of the circulating anticoagulant directed against antihemophilic factor; with notes on an essay for antihemophilic factor. Blood, 20, 137-149.

Dreyfus, J. C., Schapira, G., Scebat, L., Renais, J., and Lenègre, J. S (1960). Les enzymes seriques dans le diagnostic des lesions $\omega$ myocardiques d'origine coronarienne. II. Rev. Atherosclér.,
$2,187-192$.

Ebashi, S., Toyokura, Y., Momoi, H., and Sugita, H. (1959). High creatine phosphokinase activity of sera of progressive muscular dystrophy. J. Biochem. (Tokyo), 46, 103-104.

Forbes, C. D., King, J., and McNicol, G. P. (1971). Duplication of L.D.H. -1 , in a patient receiving multiple transfusions. Clin. Chem., 17, 948-949. 
Graig, F. A., and Ross, G. (1963). Serum creatine phosphokinase in thyroid disease. Metabolism, 12, 57-59.

Griffiths, P. D. (1966) Serum levels of A.T.P: creatine phosphotransferase (creatine kinase). The normal range and effect of muscular exercise. Clin. chim. Acta, 13, 413-420.

International Union of Biochemistry (1961). Report of the Commission of Enzymes. Pergamon Press, Oxford.

International Union of Biochemistry (1965). Enzyme Nomenclature. Elsevier, Amsterdam.

King, J. (1970). Practical Clinical Enzymology. Van Nostrand, London.

McQueen, M. J., Garland, I. W. C., and Morgan, H. G. (1972). 'Glycerate dehydrogenase' activity in acute myocardial infarction and myocardial ischemia. Clin. Chem., 18, 275279.

Neumann, G. J. (1968). The determination of normal ranges from routine laboratory data. Clin. Chem., 14, 979-988.
Okinaka, S., Kumagai, H., Ebashi, S., Sugita, H., Momoi, H., Toyokura, Y., and Fujie, Y. (1961). Serum creatine phosphokinase: activity in progressive muscular dystrophy and neuromuscular diseases. Arch. Neurol. (Chic.), 4, 520-525.

Remmers, A. R., Jr., and Kaljot, M. V. (1963). Serum transaminase levels: effect of strenuous and prolonged physical exercise on healthy young subjects. J. Amer. med. Ass., 185, 968-970.

Schmidt, E., and Schmidt, F. W. (1967). Guide to Practical Enzyme Diagnosis, p. 81. Boehringer, Mannheim.

Schneider, K. W., and Heise, E. R. (1963). Die diagnostische Bedeutung einer erhöhten Kreatin-Phosphokinase-Aktivatat im Serum. Dtsch. med. Wschr., 88, 520-525.

Wright, N., Clarkson, A. R., Brown, S. S., and Fuster, V. (1971). Effects of poisoning on serum enzyme activities, coagulation and fibrinolysis. Brit. med. J., 3, 347-350. 